\title{
Estimate of Glomerular Filtration Rate among Players of a West African Football Team during a Competition
}

\section{Jacques Vigan ${ }^{*}$, Hugues FA Ehoue ${ }^{2}$, Cedric EP Bigot ${ }^{3}$, Wilfried Agbodjogbe ${ }^{2}$, Seraphin Ahoui ${ }^{4}$, Pierre Dansou $^{2}$ and Andre Bigot ${ }^{5}$}

${ }^{1}$ Department of Nephrology, Faculty of Health Sciences, University of Abomey-Calavi, Benin

${ }^{2}$ Effort of Physiology Laboratory of the National Institute of Youth, Physical Education and Sports, Hospital of Cotonou, Benin

${ }^{3}$ Forensic Unit of the Faculty of Health Sciences, Hospital of Cotonou, Benin

${ }^{4}$ Department of Nephrology, Teaching Hospital of Borgou, Benin

${ }^{5}$ Blood Bank of the National Academic Hospital of Cotonou, Benin

${ }^{*}$ Corresponding author: Vigan Jacques, Nephrologist, Faculty of Health Sciences, University of Abomey-Calavi, 071BPBP64 Kouhounou, Benin, Tel: 00229946245 22; $0022996997449 ;$ E-mail: viques2@yahoo.fr

Received date: May 11, 2017; Accepted date: May 22, 2017; Published date: May 30, 2017

Citation: Vigan J, Ehoue HFA, Bigot EBC, Agbodjogbe W, Ahoui S, et al. (2017) Estimate of Glomerular Filtration Rate among Players of a West African Football Team during a Competition. J Clin Exp Nephrol 1: 36. doi: 10.21767/2472-5056.100036

Copyright: (C) 2017 Vigan J, et al. This is an open-access article distributed under the terms of the Creative Commons Attribution License, which permits unrestricted use, distribution, and reproduction in any medium, provided the original author and source are credited.

\section{Abstract}

Introduction: A football match could cause transient adverse effects in the players' kidney function. The purpose of this study is to determine the development of glomerular filtration rate among football players during a match and a competition in Benin.

Methods: It was a cross-sectional and descriptive study conducted from November 2015 to May 2016. Participants included black footballer, aged above 17 years, who has been residing in Benin for at least one year, attending regular training sessions and having given his informed consent to participate in the study. During a series of 4 matches, blood sampling was regularly carried out before, just at the end and 24 hours after each match. Glomerular filtration rate (GFR) was estimated by CKD-EPI formula from blood creatinine.

Results: A total of 14 players were included in each match. The participating players were averagely aged $23 \pm 2.21$ years and had 2 years of experience in first division football. The estimate of the players' medium GFR during the $1^{\text {st }}$ match was $129.35 \pm 17.39 \mathrm{ml} / \mathrm{min} / 1.73 \mathrm{~m}^{2}$ before the beginning, $90.31 \pm 17.39 \mathrm{ml} / \mathrm{min} / 1.73 \mathrm{~m}^{2}$ at the end and $123.96 \pm 18.72 \mathrm{ml} / \mathrm{min} / 1.73 \mathrm{~m}^{2} 24$ hours later. During a 4match competition, the GFR declines at the end of each match and rise up again in the next 24 hours.

Conclusion: The glomerular filtration rate declines drastically and transiently during a match of football competition in a hot and humid climate. There is need for players to rehydrate before, during and after each match.
Keywords: Benin; CKD-EPI; Glomerular filtration rate; Football; Hot and humid climate

\section{Introduction}

Physical activity is associated with disruptions of the body's homeostasis. These disruptions can cause the development of adaptive responses which, in the long term, are translated into the physical condition. However, the maintenance (and most often the improvement) of the individual's health condition requires that constraints due to the physical activity are perfectly tolerated by the body [1].

The benefits of regular physical activity are reflected through an improvement of the well-being, a reduction in the incidence of cardio-vascular diseases and a longer lifespan [2].

Kidneys allow maintaining their own normal value of the individual's vital signs. They are involved in the elimination of many substances, the control of acids-bases balance and blood pressure regulation $[3,4]$.

Kidneys play multiple and complex roles, however the Glomerular Filtration Rate (GFR) is the best evidence of all these functions [5]. GFR is the quantitative variable which best defines kidney function, and it is a vital parameter in the assessment of renal function [6]. In clinical practice, the glomerular filtration rate is estimated from blood biomarkers of which the most used is the determination of serum creatinine [7].

Physical activity leads to significant changes in the renal hemodynamics and in the urinary excretion of electrolytes and proteins $[8,9]$.

During physical effort, the increase in blood flow to the muscles leads to a decline of the splanchnic and renal perfusion. This decline is directly proportional to the degree and duration 
of the effort. During intense exercises, renal blood flow can drop up to $25 \%$ of its value at rest [10]. This gradual decline of renal blood flow can cause ischemia in renal function, thus disrupting or slowing their normal function [11]. The decline in Glomerular Filtration Rate (GFR) is one of the most frequent malfunctions observed during and after an intense physical effort $[12,13]$.

Football is a collective sport characterized by long-term efforts with variable intensities interspersed with periods of incomplete recovery, which could cause serious changes in kidney function. Few studies conducted on collective sports practiced by children and adolescents, revealed that football recorded most of the post-effort kidney damage ( $62 \%$ of various kidney damage) $[14,15]$.

In southern Benin, collective sports are practiced, regardless of the sport season. Nevertheless, the exposure to heat and relative humidity can cause dehydration which may worsen GFR. That is why we decided to study the development of GFR among football team players during a competition.

\section{General Objective}

To study the development of estimated Glomerular Filtration Rate (eGFR) among football team players during a competition in a sub-equatorial climate of Southern Benin.

\section{Specific Objectives}

- Determine the development of eGFR during a match.

- Determine the development of eGFR during a competition among football team players.

\section{Methods}

The framework of the study was:

- The stadium of Project Goal FIFA (International Federation of African Football) training center located in Missérété within AKPRO MISSERETE district, in eastern part of Porto Novo.

- Biomedical analyzes lab of MAHOUNA Polyclinic.

It was a cross-sectional study of experimental and descriptive type conducted from November 2015 to May 2016.

The study population included senior players of a football team in Benin $1^{\text {st }}$ division. They were from OUSSOU SAKA (ASSOS) sports club of Porto-Novo, a team that has been in Benin first division for several years. The consecutive sampling is not probabilistic. We received the approval of the team's managers and the informed consent of the players who agreed to make themselves available to follow all procedures in compliance with the Declaration of Helsinki.

Participants included were black footballer, aged above 17 years, who has been residing in Benin for at least one year, holding a sports license validated for the first division of the ongoing championship, duly registered to compete at different levels and having given his informed consent to participate in the study.
Those excluded in the study were homozygous players with sickle cell anemia SS; vegetarian, hypertensive, diabetic subjects; subjects with impaired kidney function; subjects with a gradually-developing intercurrent condition and subjects undergoing antihypertensive, diuretic, anti-inflammatory therapy or any other therapy which is likely to influence renal parameters.

Any player who does not play at least forty-five (45) minutes of a match was excluded from the study.

The Glomerular Filtration Rate is the dependent variable, and it was estimated on the basis of the equation CKD-EPI (Chronic Kidney Disease Epidemiology). This equation is considered as one of the most valid and reliable formulas because it is more accurate for creatinine clearance values above $60 \mathrm{ml} / \mathrm{min} / 1.73$ $\mathrm{m}^{2}$ (Table 1).

Table 1. CKD-EPI formula [16].

\begin{tabular}{|l|l|lll|}
\hline Africans & $\begin{array}{l}\text { Serum Creatinine } \\
\boldsymbol{\mu m o l} / \mathbf{L}(\mathbf{m g} / \mathbf{d L})\end{array}$ & Formulas & \\
\hline Men & $\leq 80(\leq 0.9)$ & $\begin{array}{l}\text { GFR=163 } \\
(0.993) \text { age }\end{array}$ & $($ Creat/0.9)-0,411 $\times$ \\
\cline { 2 - 5 } & $>80(>0.9)$ & $\begin{array}{l}\text { GFR=163 } \\
(0.993) \text { age }\end{array}$ & $($ Creat/0.9)-1,209 & \\
& & & \\
\hline
\end{tabular}

The dosage of serum creatinine levels has been carried out through enzymatic method after calibration by reference technique: Isotopic Dilution Mass Spectrometry (IDMS). A standard quality control and pathological control were conducted at the beginning and end of handling. The device used for this dosage is the automated biomedical analyzer "flexor Junior". The independent variables were.

Socio-demographic characteristics: Age, sex, level of education, occupation, origin and number of years of experience in $1^{\text {st }}$ Division football.

Anthropometric variables: Body mass, height, Body Mass Index (BMI) or Quetelet index which is an individual's body weight divided by the square of his/her height; the Body Surface Area (BSA) is calculated using Boyd formula:

$B S A=0.0001 \times(3,207) \times(P 0,7285-0,0188 \log P) \times(T 0.3)$

$\mathrm{P}=$ Weight in $\mathrm{g}, \mathrm{T}=$ Height in $\mathrm{cm}$ and $\mathrm{BSA}$ in $\mathrm{m}^{2}$.

Clinical data: The internal temperature (IT), blood pressure (BP) and heart rates (HR) at rest and after effort are recorded with an automatic upper arm blood pressure monitor certified by the European Society of Hypertension. Three successive measurements were carried out and the average was selected for the BP. The measurements were recorded before the kick-off of the match while respondents were at rest for at least 15 minutes; they were recorded again at the end of the match and $24 \mathrm{~h}$ later.

We used a previously designed survey questionnaire including the socio-demographic characteristics, anthropometric, clinical and biological variables. Data collection was carried out by a team made up of a doctor, a research Master student in the field 
of science and technology of physical activities and sports, a state registered nurse and a lab technician.

Based on the list of players (number, name and surname) selected by the coach for the match, the different tubes were previously labelled. For the $1^{\text {st }}$ match, we met the players on their lodging site $3 \mathrm{~h}$ prior to the kick-off of the match. After a brief interview, they were called upon one after the other to be administered the questionnaire. The identity and medical history are then documented. Then we recorded the body mass, height, the internal temperature, blood pressure (BP) and heart rate (HR) at rest. After this step, $4 \mathrm{~mL}$ of venous blood were taken from the back of the hand or from the bend of the elbow in a dry tube. A compression and a dressing of the puncture site were made and the player was thanked for participating. All players selected for this match were attended to equally. Two people were in charge of filling the forms and measuring the different vital signs while the other two took care of blood samples.

At the end of the match, the different vital signs (BP, HR, internal temperature) were recorded once again. The tubes were labelled with the names and numbers of those who actually played for at least 45 minutes. Another $4 \mathrm{~mL}$ of venous blood sample was taken from these latter. Pre and post-match blood samples were stored in a cooler equipped with accumulators. They were immediately sent to MAHOUNA Polyclinic lab and processed the same day.

The following day i.e. $24 \mathrm{~h}$ after the match, we met the players to record their vital signs and the same blood sampling were carried out.

In the $2^{\text {nd }}, 3^{\text {rd }}$ and $4^{\text {th }}$ matches, we used the same procedure for data collection except for the identity and medical history which were already recorded during the $1^{\text {st }}$ match.

During the study period, the ambient temperature varied between $36^{\circ} \mathrm{C}$ and $31^{\circ} \mathrm{C}$ at the beginning and $28^{\circ} \mathrm{C}$ to $30^{\circ} \mathrm{C}$ at the end of the matches. Relative humidity varied between 80 to $68 \%$ at the beginning and 63 to $70 \%$ at the end of the matches.

Data entry was carried out using Epi-DATA 3.1. For all the processing, the significance level of statistical tests was set at $p<0.05$ and confidence interval at $95 \%$.

\section{Results}

Globally, fifteen (15) players met our inclusion criteria. Later on, one (01) of them refused the blood sampling, so our sample size was reduced to fourteen (14) players.

\section{General characteristics of the sample}

Socio-demographic characteristics: The players' average age was $23.14 \pm 2.21$ years with extreme values of 20 and 28 years. The most represented age range was 23 to 26 years. All respondents were educated, and 10 out of 14 had a university education level. Most of the players were students but all were professional footballers. Half (7 out of 14 ) or $50 \%$ of the total number of these players lived in urban area. Over half or $57.14 \%$ ( 8 out of 14 ) of the players had less than 2 years of professional football experience in Benin $1^{\text {st }}$ division. The rest of the general characteristics is outlined in Table 2.

Table 2. Socio-demographic characteristics of the sample 4.1.2Anthropometric characteristics of football players.

\begin{tabular}{|c|c|c|c|}
\hline & & Total $(\mathrm{N}=14)$ & Rate (\%) \\
\hline \multicolumn{4}{|l|}{ Age } \\
\hline & [20-23] & 6 & 42.9 \\
\hline & {$[23-26]$} & 7 & 50.0 \\
\hline & {$[26-28]$} & 1 & 7.1 \\
\hline \multicolumn{4}{|c|}{ Level of education } \\
\hline & Secondary education & 4 & 28.6 \\
\hline & University education & 10 & 71.4 \\
\hline \multicolumn{4}{|c|}{ Profession } \\
\hline & Artisan & 1 & 7.1 \\
\hline & Cook & 1 & 7.1 \\
\hline & Pupil & 2 & 14.3 \\
\hline & Student & 10 & 71.4 \\
\hline & Professional footballer & 14 & 100 \\
\hline \multicolumn{4}{|c|}{ Place of origin } \\
\hline & Urban areas & 7 & 50.0 \\
\hline & Suburban areas & 7 & 50.0 \\
\hline \multicolumn{4}{|c|}{ Experience in 1st division football } \\
\hline & $<2$ years & 8 & 57.2 \\
\hline & 2-5 Years & 4 & 28.6 \\
\hline & $5-10$ years & 1 & 7.1 \\
\hline & $\geq 10$ years & 1 & 7.1 \\
\hline
\end{tabular}

The medium body weight was $66.14 \pm 7.33 \mathrm{~kg}$, medium height was $1.73 \pm 0.05 \mathrm{~m}$ and medium body mass index was $22.12 \pm$ $1.57 \mathrm{~kg} / \mathrm{m}^{2}$ (Table 3).

Table 3. Anthropometric characteristics of the players. $B M=B o d y$ Mass; BMI=Body Mass Index; BSA=Body Surface Area.

\begin{tabular}{|l|l|l|}
\hline & Medium & Standard deviation \\
\hline BM $(\mathrm{kg})$ & 66.14 & 7.33 \\
\hline Height $(\mathrm{m})$ & 1.73 & 0.05 \\
\hline BMI $\left(\mathrm{kg} / \mathrm{m}^{2}\right)$ & 22.12 & 1.57 \\
\hline BSA $\left(\mathrm{m}^{2}\right)$ & 1.08 & 0.01 \\
\hline
\end{tabular}

Clinical data of the players: The players'medium internal temperature did not vary significantly between the beginning and the end of a match. Except for the first match, the medium systolic and diastolic blood pressure slightly declined from the beginning to the end of the match. The players'heart rate 
slightly increased from the beginning to the end of the match. Table 4 highlights the different variations of these clinical data.

Table 4. Distribution of players according to clinical data during the competition. IT=Internal Temperature; SBP=Systolic Blood Pressure; DBP=Diastolic Blood Pressure; HR=Heart Rate.

\begin{tabular}{|l|l|l|l|l|l|}
\hline & IT $\left({ }^{\circ} \mathbf{C}\right)$ & SBP $(\mathbf{m m H g})$ & $\begin{array}{l}\text { DBP } \\
(\mathbf{m m H g})\end{array}$ & $\begin{array}{l}\text { HR } \\
\mathbf{m i n})\end{array}$ \\
\hline \multicolumn{5}{|l|}{$1^{\text {st }}$ Match $(\mathrm{n}=14)$} \\
\hline Pre-match & $36 \pm 0.5$ & $\begin{array}{l}126.14 \\
\pm 14.82\end{array}$ & $\begin{array}{l}75.71 \\
9.20\end{array}$ & \pm & $\begin{array}{l}71.71 \\
10.18\end{array}$ \\
\hline
\end{tabular}

$3^{\text {rd }}$ match $(n=14)$

Table 5. Development of the players eGFR during the $1^{\text {st }}$ match.

\begin{tabular}{|c|c|c|c|c|c|c|}
\hline \multirow[b]{2}{*}{ Players } & \multicolumn{2}{|l|}{ Beginning match } & \multicolumn{2}{|l|}{ End match } & \multicolumn{2}{|c|}{24 hours after the match } \\
\hline & $\begin{array}{l}\text { Serum creatinine } \\
(\mathrm{mg} / \mathrm{dl})\end{array}$ & $\begin{array}{l}\text { eGFR } \\
\left(\mathrm{ml} / \mathrm{min} / 1.73 \mathrm{~m}^{2}\right)\end{array}$ & $\begin{array}{l}\text { Serum creatinine } \\
(\mathrm{mg} / \mathrm{dl})\end{array}$ & $\begin{array}{l}\text { eGFR } \quad(\mathrm{ml} / \mathrm{min} / 1.73 \\
\left.\mathrm{m}^{2}\right)\end{array}$ & $\begin{array}{l}\text { Serum creatinine } \\
(\mathrm{mg} / \mathrm{dl})\end{array}$ & $\begin{array}{l}\text { eGFR } \quad(\mathrm{ml} / \mathrm{min} / 1.73 \\
\left.\mathrm{m}^{2}\right)\end{array}$ \\
\hline 1 & 0.73 & 145.93 & 1.19 & 95.52 & 0.84 & 137.68 \\
\hline 2 & 0.76 & 149.95 & 1.28 & 91.66 & 0.76 & 149.87 \\
\hline 3 & 0.95 & 131.74 & 1.25 & 94.36 & 0.98 & 126.42 \\
\hline 4 & 1.20 & 96.67 & 1.58 & 69.09 & 1.07 & 110.81 \\
\hline 5 & 1.02 & 121.31 & 1.65 & 68.21 & 1.14 & 106.65 \\
\hline 6 & 0.75 & 149.80 & 1.17 & 100.99 & 0.75 & 149.88 \\
\hline 7 & 0.89 & 137.44 & 1.32 & 86.06 & 1.01 & 118.95 \\
\hline 8 & 0.83 & 142.58 & 1.06 & 112.74 & 0.83 & 142.58 \\
\hline 9 & 1.00 & 122.96 & 1.26 & 92.80 & 1.26 & 92.89 \\
\hline 10 & 1.15 & 102.82 & 1.28 & 90.30 & 1.15 & 102.82 \\
\hline 11 & 0.86 & 141.16 & 1.18 & 99.65 & 0.89 & 139.32 \\
\hline 12 & 1.13 & 107.34 & 1.29 & 91.83 & 1.13 & 107.34 \\
\hline 13 & 0.97 & 125.06 & 1.70 & 63.61 & 1.05 & 114.02 \\
\hline 14 & 0.92 & 136.18 & 1.12 & 107.56 & 0.92 & 136.18 \\
\hline Average & 0.94 & 129.35 & 1.31 & 90.31 & 0.98 & 123.96 \\
\hline $\begin{array}{l}\text { standard } \\
\text { deviation }\end{array}$ & 0.15 & 17.39 & 0.19 & 14.48 & 0.16 & 18.72 \\
\hline
\end{tabular}

\section{Development of eGFR during a competition}

The data of the first match are shown above. During the $2^{\text {nd }}$ match, the players medium eGFR value declined drastically from $128.19 \mathrm{~mL} / \mathrm{min} / 1.73 \mathrm{~m}^{2}$ before the match to $85.17 \mathrm{~mL} / \mathrm{min} / 1.73$ $\mathrm{m}^{2}$ at the end of the match representing a significant decline of

\begin{tabular}{|l|l|l|l|l|}
\hline Pre-match & $36 \pm 0.5$ & $\begin{array}{l}131.14 \\
16,64\end{array}$ & $\begin{array}{l}76.79 \\
0.87\end{array}$ & $62.86 \pm 11.03$ \\
\hline Post-match & $\begin{array}{l}36.29 \\
0.47\end{array}$ & $117.07 \pm 9.21$ & $73 \pm 11.93$ & $99.35 \pm 8.02$ \\
\hline \multicolumn{7}{|l|}{$4^{\text {th }}$ match $(n=14)$} \\
\hline Pre-match & $\begin{array}{l}36.14 \\
0.36\end{array}$ & $132.64 \pm 7.52$ & $79 \pm 13.60$ & $70.35 \pm 11.99$ \\
\hline Post-match & $\begin{array}{l}36.21 \\
0.43\end{array}$ & $\begin{array}{l}120.57 \\
11.13\end{array}$ & $\begin{array}{l}70.29 \\
13.63\end{array}$ & $\begin{array}{l}101.93 \\
5.78\end{array}$ \\
\hline
\end{tabular}

Development of the players eGFR during the $1^{\text {st }}$ match

During the $1^{\text {st }}$ match, the players medium eGFR value declined drastically from $129.35 \mathrm{~mL} / \mathrm{min} / 1.73 \mathrm{~m}^{2}$ before the match to $90.31 \mathrm{ml} / \mathrm{min} / 1.73 \mathrm{~m}^{2}$ at the end of the match representing a significant decline of $30.18 \%$ with $p<0.001$. It rises back to $123.96 \mathrm{~mL} / \mathrm{min} / 1.73 \mathrm{~m}^{2} 24$ hours after the match. The development of the estimated GFR is shown in Table 5.
$33.55 \%$ with $p<0.001$. It rises back to $127.88 \mathrm{~mL} / \mathrm{min} / 1.73 \mathrm{~m}^{2} 24$ hours after the match.

During the $3^{\text {rd }}$ match the players medium eGFR value declined drastically from $116,13 \mathrm{~mL} / \mathrm{min} / 1.73 \mathrm{~m}^{2}$ before the match to $89.78 \mathrm{ml} / \mathrm{min} / 1.73 \mathrm{~m}^{2}$ at the end of the match representing a 
significant decline of $22.69 \%$ with $p<0.001$. It rises back to $127.61 \mathrm{~mL} / \mathrm{min} / 1.73 \mathrm{~m}^{2} 24$ hours after the match.

During the $4^{\text {th }}$ match, the players medium eGFR value declined drastically from $133 \mathrm{~mL} / \mathrm{min} / 1.73 \mathrm{~m}^{2}$ before the match to $100.42 \mathrm{~mL} / \mathrm{min} / 1.73 \mathrm{~m}^{2}$ at the end of the match representing a significant decline of $24.94 \%$ with $p<0.001$. It rises back to $129.61 \mathrm{~mL} / \mathrm{min} / 1.73 \mathrm{~m}^{2} 24$ hours after the match.

During the competition (set of four matches) the eGFR declined drastically at the end of matches and rises back 24 hours after matches to nearly reach pre-match value (Figure 1).

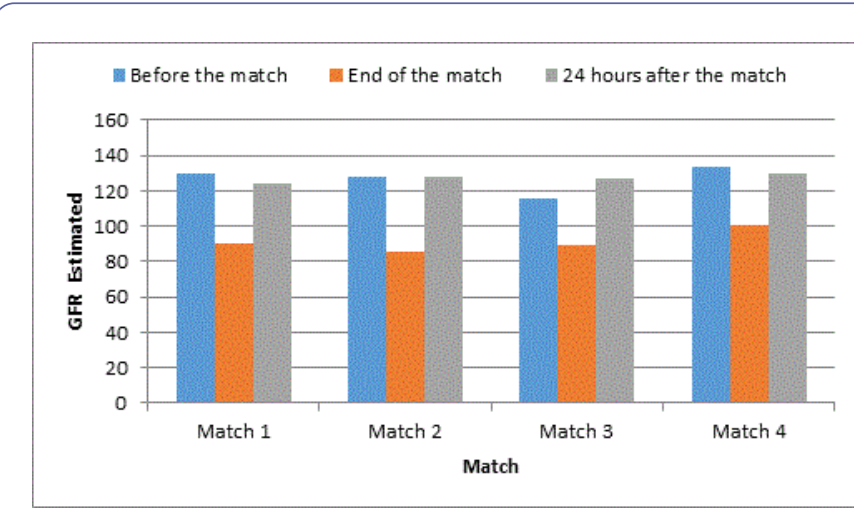

Figure 1: Development of the GFR during a competition.

\section{Discussion}

The purpose of this study is to identify renal function disruptions in southern Benin climatic environment among $1^{\text {st }}$ division football players.

Intense physical exercises induce a decline in renal hemodynamic in relation with greater burdens on active muscle tissue and the skin [17].

At the end of the matches, the drastic eGFR decline varied between $22.69 \%$ and $33.55 \%$. A similar observation was made by Gouthon and al in 2009, on female basketball players in subSaharan Africa, where at the end of the match, the eGFR declined drastically in the winning team $(-27.32 \%, p=0.046)$ and the losing team $(-35.45 \%, p=0.020)$ [18]. Similarly, a decline of $19 \%(p=0.017)$ of the eGFR was observed at the end of a series of two matches among female handball players in Benin $1^{\text {st }}$ division in 2012, in the same environment as in this study [19]. In Italy, in 2011, Tian and al also recorded among adolescent semi-marathon runners a decline of GFR values estimated by MDRD formula ranging from $101.2 \pm 10.0 \mathrm{~mL} / \mathrm{min} / 1.73 \mathrm{~m}^{2}$ at the beginning of the race to $78.0 \pm 11.1 \mathrm{~mL} / \mathrm{min} / 1.73 \mathrm{~m}^{2} 2$ hours later and $77.6 \pm 12.7 \mathrm{~mL} / \mathrm{min} / 1.73 \mathrm{~m}^{2}$ after 4 hours race. Therefore, there was a $20 \%$ decline in the eGFR [20].

The football played in the climate of southern Benin certainly creates kidney function disruption due to the substantial eGFR decline. The eGFR decline at the end of matches is the consequence of kidney blood flow decline to the benefit of active muscles, as a result of cardiac output redistribution $[2,13]$.
The next day, or 24 hours after matches, the eGFR recorded values rose back to nearly pre-match values. The same observations were made among female Benin handball players as $26 \mathrm{~h}$ after matches, the eGFR values rose back to nearly prematch values [19]. In the 24 hours following the end of the basketball match, the eGFR increased progressively up to a significantly higher value than the one recorded at rest in the winning team $(+11.75 \%, p=0.02)$ [18]. Therefore, the kidney disruption created by football disappears 24 hours after matches. This observation is consistent with observations made by several authors $[2,13,20]$ confirming that: kidney function disruption induced by physical effort is transient and disappears within few hours after the end of the effort, or $24 \mathrm{~h}$ later [20]. These results reflect a transient kidney burden in relation with the dehydration which is inadequately compensated by the players during matches $[21,22]$. Scientists are much concerned with football players' hydration conditions. Barbosa reported in 2012 that an official football match significantly impairs players' hydration and this is correlated with the time spent in the match [23]. Similarly, Williams showed among young football players that 14 out of 21 were already dehydrated before the beginning of the training. He concluded that there was a wide variation of hydration conditions among these players and suggested adequate hydration during training sessions [24].

\section{Conclusion}

During a football match, particularly in a hot and humid environment such as southern Benin, players present a significant decline in glomerular filtration rate. This decline is transient and repetitive at each match throughout the competition. These results can be explained by inadequate players' hydration during matches.

It is therefore important to persuade players on the need for adequate hydration before, during and after matches during a competition.

\section{References}

1. Koulmann N, Banzet S, Bigard AX (2003) L'activite physique à la chaleur: de la physiologie aux recommandations d'apport hydrique Med Trop 63: 617-626.

2. Goffin E, Nielens H (2006) Peut-on pratiquer un sport lorsqu'on est insuffisant renal chronique, dialysé ou transplanté ? AIRG-France Informations Médicales 20: 1-4.

3. Massoud C, Taourel P, Goze-B, Zanca M (2011) Evaluation du débit de filtration glomérulaire par imagerie par résonnance magnétique. Elsevier Masson SAS et Editions françaises de radiologie 92: 369-381.

4. Gougoux A (2005) Physiologie des reins et des liquides corporels. Québec: Multimondes pp: 336.

5. Roland M, Guiard E, Karras A, Jacquot C (2011) Pourquoi la clairance de la créatinine doit-elle céder la place aux formules d'estimation du débit de filtration glomérulaire ? Revue Francophone des Laboratoires. Elsevier Masson SAS 429: 28.

6. Flamant M, Boulanger H, Azar H, Vrtovsnik F (2010) Mesure et estimation du débit de filtration glomérulaire: quels outils pour la 
prise en charge de la maladie rénale chronique ? La presse médicale 39: 303-311.

7. Delanaye P, Mariat C, Moranne O, Cavalier E, Flamant M (2012) L'estimation du debit de filtration glomérulaire en 2012: quelle valeur ajoutée pour la nouvelle équation CKD-EPI? Elsevier Masson. Néphrologie et Thérapeutique 8: 199-205.

8. Mc Allister RM (1998) Adaptations in control of blood flow with training: splanchnic and renal blood flows. Med Sci Sports Exerc 30: $375-381$.

9. Lippi G, Sanchis-Gomar F, Salvagno GL, Aloe R, Schena F, et al. (2012) Variation of serum and urinary neutrophil gelatinase associated lipocalin (NGAL) after strenuous physical exercise. Clin Chem Lab Med 50: 1585-1589.

10. Castenfors J (1977) Renal function during prolonged exercise. Ann NY Acad Sci 301: 151-159.

11. Collins AJ (2003) The hemoglobin link to adverse outcomes. Adv Studies in Medcine 3: S194-S197.

12. Bellinghieri G, Savica V, Santoro D (2008) Renal alterations during exercice. J Ren Nutr 18: 158-164.

13. Poortmans JR (1995) La réponse rénale à l'exercice chez le sujet sain et pathologique. Néphrol 16: 317-324.

14. Gerstenbluth RE, Spirnak JP, Elder JS (2002) Sports participation and high grade renal injuries in children. J Urol 168: 2575-2578.

15. Wan J, Corvino TF, Greenfield SP, Discala C (2003) Kidney and testicle injuries in team and individual sports: data from the national pediatric trauma registry. J Urol 170: 1528-1533.

16. de Santé (2011) Rapport d'évaluation technologique de la haute autorité de santé. Evaluation du débit de filtration glomérulaire, et du dosage de la créatininémie dans le diagnostic de la maladie rénale chronique chez l'adulte. Note de cadrage. Saint-Denis La Plaine. pp: 8-20.

17. Musa I, Mabrouk MA, Tanko Y (2016) Renal function test parameters in male football players. Intl J App Exer Physiol 5: 20-26.

18. Gouthon P, Tonon BA, Ouendo EM, Falola JM, Agboton B, et al. (2009) Evolution des paramètres associés à la fonction rénale après un match de basketball en milieu africain subsaharien. Sciences \& Sports 24: 293-301.

19. Tonon BA, Agboton B, Falola JM, Gouthon P, Bio Nigan I, et al. (2012) Renal responses to series of handball games played in subSaharan environment by amateur Division 1 of female players. APE 2: 103-109.

20. Tian Y, Tong K, Lippi G, Huang C, Shi Q, et al. (2011) Renal function parameters during earling and late recorvery periods following an all-out $21 \mathrm{~km}$ run intrained adolescent runners. Clin Chem Lab Med 49: 993-997.

21. Da Silva Al, Fernandez R (2003) Dehydration of Football Referees During a Match. Br J Sports Med 37: 502-506.

22. Aristotelis G (2016) Biochemical Changes From Preparation to Competitive Period in Soccer. Intl J Sci Cul Sport 4: 150-161.

23. Barbosa-Coelho D, Rodrigues PE, Couto E, Coehlo L, Dias Soares D, et al. (2012) Evaluation of Hydration Status Following Soccer Matches of Different Categories. Rev Bras Cineantropom Desempenho Hum 14: 276-286.

24. Williams CA, Blackwell J (2012) Hydration Status, Fluid Intake, and Electrolyte Losses in Youth Soccer Players. Int J Sports Physiol Perform 7: 367-374. 